\title{
Rational Emotive Therapy untuk Remaja Berpikiran Negatif: Elaborasi Doktrin QS At-Tin : 4
}

\author{
Ahmad Putra \\ Pascasarjana UIN Sunan Kalijaga Yogyakarta
}

Korespodensi dengan Penulis:

Ahmad Putra: Telp: 082387636604

E-mail: pratamaahmad954@gmail.com

\begin{abstract}
Keywords:
Rational

emotive therapy, teenagers, negative mind, Islamic doctrin.
\end{abstract}

\section{Abstract}

This research explains the efforts of rational emotive therapy for adolescents with negative thoughts about their bodies which are not ideal. As a result of these negative thoughts, the client feels hopeless and disappointed so he feels there is no chance to reach the desire to become a member of the police. The method used in this research is qualitative research with case study research which is then analyzed using comparative descriptive analysis. While data is collected through interviews and observations. After the data is collected, then analyzed to find out the counseling process with rational emotive therapy and elaborated with At-Tin verse 4. Then do not forget to compare before and after the counseling process. The counseling process with rational emotive therapy is done in steps: problem identification, diagnosis, prognosis, therapy, and evaluation. The results found after the counseling process and elaborated with At-Tin verse 4 is that the client realizes that what he has perceived so far is wrong and intends to think rationally in dealing with a problem. Negative assumptions that arise in the mind of the client will only be a burden and an obstacle in achieving a goal. In the end, the client is motivated to try to achieve his goals by diligently exercising, not quickly getting prejudiced by body shape, learning to be grateful to the body that God gave, not complaining, keeping eating patterns and the client believes nothing is impossible if there is an effort of heart.

\begin{abstract}
Abstrak
Penelitian ini menjelaskan upaya rational emotive therapy untuk remaja berpikiran negatif terhadap tubuhnya yang tidak ideal. Imbas dari pikiran negatif, klien merasa putus asa dan kecewa sehingga merasa tidak ada kesempatan untuk menggapai keinginan menjadi anggota kepolisian. Metode yang digunakan dalam penelitian ini ialah penelitian kualitatif dengan jenis penelitian studi kasus yang kemudian dianalisa menggunakan deskriptif komparatif. Data dikumpulkan melalui wawancara dan observasi. Setelah data terkumpul, lalu dianalisis untuk mengetahui proses konseling dengan rational emotive therapy dan dielaborasikan dengan At-Tin ayat 4. Lalu tidak lupa membandingkan sebelum dan sesudah dilakukannya proses konseling. Proses konseling dengan rational emotive therapy
\end{abstract}


dilakukan dengan langkah: identifikasi masalah, diagnosis, prognosis, terapi, dan evaluasi. Hasil yang ditemukan setelah dilakukannya proses konseling dan dielaborasikan dengan At-Tin ayat 4 ialah klien menyadari bahwa apa yang ia persepsikan selama ini adalah salah. Kemudian, berniat untuk berpikir rasional dalam menghadapi sebuah permasalahan. Anggapan negatif yang muncul pada pikiran klien hanya akan menjadi sebuah beban dan penghambat dalam mencapai sebuah cita-cita. Pada akhirnya, klien termotivasi untuk berusaha mencapai cita-citanya dengan cara rajin berolahraga, tidak cepat berburuk sangka dengan bentuk tubuh, belajar untuk bersyukur dengan tubuh yang Allah SWT beri, tidak mengeluh, menjaga pola makan dan klien yakin tidak ada yang tidak mungkin bila ada usaha dari hati.

\section{PENDAHULUAN}

Remaja sering kali dihadapkan dengan masalah-masalah yang membuat dirinya dewasa, matang ataupun cerdas, jika mengedepankan pikiran yang positif. Namun, saat negative thingking yang digunakan, maka masalah yang dihadapi akan membawa petaka. Sehingga, ketika sebuah masalah datang dan dialami oleh orang yang dapat dewasa dalam menghadapinya, maka solusi mudah ditemui. Remaja yang berpikiran positif diyakini dapat menemukan jalan keluar dari sebuah masalah yang dialaminya sehingga tidak mempengaruhi pikiran, kesehatan, tidak merasa terbebani dan tidak ada kekecewaan yang berkepanjangan.

Papalia dan Olds mengatakan bahwa remaja merupakan masa transisi dari fase kanak-kanak menuju fase dewasa yang dimulai di usia 12 atau 13 tahun dan berakhir di usia akhir belasan atau awal-awal dua puluh tahun. ${ }^{1}$ Jose RL Batubara menambahkan seseorang dikatakan remaja saat terlihat perubahan menyangkut hormonal, fisik, psikologis maupun sosialnya. ${ }^{2}$ Menariknya, perubahan yang dialami sering kali menimbulkan hubungan disharmonis antara remaja dengan orang tua. ${ }^{3}$ Ini bisa saja diakibatkan karena remaja merupakan individu yang baru beranjak selangkah menuju dewasa, di satu sisi baru mengenal mana yang benar dan salah, mencoba mengenal dunia sosial serta menerima jati diri yang telah Allah SWT berikan.

Fakta di lapangan menunjukkan bahwa masih terdapat individu yang dalam hal ini seorang remaja asal Padang Sumatera Barat yang saat ini tengah menjalani pendidikan di bangku SLTA yang mana ia bercita-cita menjadi seorang polisi. Hanya saja, keinginan yang kuat dirinya untuk menggapai cita-citanya itu terhalang karena ia merasa bahwa dengan

${ }^{1}$ Khamim Zarkasih Putro, "Memahami Ciri dan Tugas Perkembangan Masa Remaja," Aplikasia: Jurnal Aplikasi Ilmu-ilmu Agama, Vol. 17, No. 1, 2017. hlm. 25-32.

2 Jose RL Batubara, “Adolescent Development," Sari Pediatri, Vol. 12, No. 1, 2010. hlm. 21-29.

3 Miftahul Jannah, "Remaja dan Tugas-Tugas Perkembangannya dalam Islam," Jurnal Psikoislamedia, Vol. 1, No. 1, 2016. hlm. 243-256. 
tubuh yang tidak ideal mustahil akan tercapai apa yang ia inginkan. Remaja ini sesekali sering merasa minder dan malu bila ada keluarga atau teman-temannya menyuruh nantinya untuk mengikuti seleksi anggota kepolisian. Persoalan inilah yang membuat remaja yang bersangkutan ini mengalami kegalauan dan bingung harus berbuat apa, sehingga ia mudah menilai negatif masa depannya kelak ditambah dengan sedikit keputusasaannya karena tubuh yang tidak ideal.

Terkait dengan pikiran negatif dari seorang remaja yang muncul dari bentuk tubuh yang tidak ideal, bukan tidak mungkin remaja tersebut dilain sisi membanding-bandingkan tubuhnya dengan tubuh orang lain, baik itu teman-temannya maupun seseorang yang ada disekitarnya. Hal ini sesuai dengan salah satu teori sosial yaitu teori sosial comparison, yang mengatakan bahwa setiap individu akan melakukan upaya perbandingan antara keadaan dirinya dengan diri orang lain. Perbandingan tersebut terlibat dalam proses evaluasi diri seseorang, dan mengandalkan penilaian dirinya sendiri tanpa memikirkan aspek-aspek lainnya. Bila pemikiran ini terus-menerus dipertahankan bahwa penampilan fisik yang ideal adalah seperti yang dimiliki oleh para model yang ada di media masa, maka setiap orang akan membandingkan dirinya secara terus-menerus kepada standar yang sebenarnya tidak realistis dengan dirinya. Maka dengan itu, tidak heran bila orang-orang yang sebenarnya memiliki berat badan yang normal memiliki asumsi negatif terhadap dirinya karena telah terpengaruh dengan bentuk tubuh ideal di media massa yang ia lihat.4

Hal tersebut bukan tidak mungkin karena terlalu cepat menyimpulkan dan menilai buruk tubuh sendiri, sehingga ada sebuah rasa ketidaknyamanan serta ketidakterimaan dengan tubuh sendiri. Hal inilah yang bisa saja menjadikan seorang remaja atau siapa saja menganggap negatif dirinya sehingga menjadi hadangan dalam mencapai sesuatu yang diinginkannya. Pikiran negatif dan sikap cepat menyimpulkan itulah yang mesti diperbaiki, perlu memikirkan serta memahami dengan rasional sehingga tidak menimbulkan kerugian dimasa depan.

Disamping itu, emosi yang bisa saja dialami seorang remaja akan semakin terlihat disaat ia menganggap apa yang diharapkan tidak akan dapat tercapai. Emosi adalah produk yang dihasilkan oleh pemikiran manusia itu sendiri, jika ia telah menilai buruk sesuatu, maka hal-hal yang kelirupun akan mudah ia lontarkan dan tentunya ia terperangkap pada gangguan emosi. ${ }^{5}$ Pikiran negatif yang dialami remaja tersebut sejatinya memang hal yang wajar dialami oleh remaja-remaja lainnya, akan tetapi perlu mendapatkan bantuan atau pelayanan konseling sehingga pikiran negatif remaja tersebut dapat dirubah kepada pikiran yang positif yang dalam hal ini melalui rational emotive therapy.

\footnotetext{
${ }^{4}$ Astrid Gisela Herabadi, "Hubungan antara Kebiasaan Berpikir Negatif tentang Tubuh dengan Body Esteem dan Harga Diri," Makara: Sosial Humaniora, Vol. 11, No. 1, 2007. hlm. 18-23.

${ }_{5}^{5}$ Gerald Corey, Teori dan Praktek Konseling dan Psikoterapi, (Bandung: Refika Aditama, 2013). hlm. 240 .
} 
Rational emotive therapy (RET) adalah sebuah aliran yang dikembangkan oleh Albert Ellis pada tahun 1955. Terapi konseling ini memberikan penekanan terhadap hubungan kognisi, emosi dan tingkah laku yang ketiganya saling berhubungan serta mempengaruhi satu sama lain. Aina Razlin dalam Sri Hartati dan Imas Kania Rahman mengatakan bahwa terapi konseling ini mengaitkan pemikiran tidak rasional manusia dengan permasalahan emosi dan mengajarkan manusia untuk menghadapi permasalahan yang terjadi atau menghentikan sebuah masalah yang datang. ${ }^{6}$

Hal yang tidak kalah penting lagi, bahwa RET juga merupakan sebuah aliran yang berpendapat bahwa manusia terlahir memiliki potensi, baik itu untuk berpikir rasional maupun berpikir yang tidak rasional. Manusia mempunyai kecenderungan untuk memelihara dirinya, berbahagia, dan mampu mengaktualkan diri. Akan tetapi, manusia juga memiliki keinginan untuk menghancurkan dirinya sendiri, menghindari pemikiran, terpaku pada pola tingkah laku lama yang kurang bagus yang tidak memberikan pengaruh baik bagi dirinya sendiri. ${ }^{7}$

RET bertujuan untuk menghilangkan cara berpikir yang tidak logis, maksudnya ialah sebuah pemikiran yang tidak rasional dan menggantinya dengan sesuatu yang logis dan masuk akal. ${ }^{8}$ Selain itu Sulistyarini dan Mohammad Jauhar mengatakan, Rational Emotive Therapy juga bertujuan untuk memperbaiki sikap klien, persepsinya, cara dalam berpikir, keyakinan serta pandangan pada diri konseli yang irasional menjadi rasional sehingga dapat mengembangkan diri dan mencapai realisasi diri yang optimal dan benar. ${ }^{9}$ Untuk menghilangkan hal ini, konselor perlu memahami dunia konseli, perilaku konseli dari sudut konseli itu sendiri. Dalam tulisan ini, penulis mencoba menghubungkan permasalahan yang dialami oleh remaja yang berpikir negatif karena tubuhnya yang tidak ideal dengan menggunakan pendekatan rational emotive therapy dan dielaborasikan dengan QS. At-Tin ayat 4 . Sehingga menarik melihat bagaimana sebuah permasalahan yang dialami seorang remaja ditangani melalui metode konseling dan dengan ayat suci al-qur'an.

\section{METODE}

Metode yang digunakan dalam penelitian ini ialah penelitian kualitatif dengan jenis penelitian studi kasus yang kemudian dianalisa menggunakan deskriptif komparatif. Menurut Denzin dan Licolin sebagaimana dikutip oleh Lexy J. Moleong menjelaskan bahwa penelitian kualitatif adalah penelitian yang menggunakan latar ilmiah dengan tujuan

6 Imas Kania Rahman, "Konsep Pendekatan Rational Emotive Behavior Therapy (Rebt) Berbasis Islam untuk Membangun Perilaku Etis Siswa," Genta Mulia, Vol. 8, No. 2, 2017. 13-26.

${ }^{7}$ Gerald Corey, Teori dan Praktek Konseling.... hlm. 238.

8 Dewa Ketut Sukardi, Pengantar Teori Konseling: Suatu Uraian Ringkas, (Jakarta: Ghalia Indonesia, 1985). hlm. 89.

9 Sulistyarini dan Mohammad Jauhar, Dasar-dasar Konseling, (Jakarta: Prestasi Pustakarya, 2014). hlm. 243. 
mendeskripsikan fenomena yang terjadi dan dilakukan dengan menggunakan berbagai metode yang ada. ${ }^{10}$

Lalu, analisis deskriptif komparatif adalah sebuah teknik yang digunakan untuk membandingkan kejadian-kejadian yang terjadi disaat penulis menganalisis kejadian tersebut dan dilakukan secara terus menerus. ${ }^{11}$ Analisis yang digunakan tersebut untuk mengetahui proses serta keberhasilan pelaksanaan konseling rational emotive therapy yang dielaborasikan dengan QS At-Tin ayat 4 terhadap seorang remaja yang berpikiran negatif karena tubuh yang tidak ideal yang menghambat semangatnya dalam menggapai cita-cita menjadi anggota kepolisian.

Sedangkan data didipatkan melalui observasi dan wawancara. Observasi merupakan suatu penelitian yang dijalankan secara sistematis dan sengaja di adakan dengan menggunakan alat indra terutama mata atas kejadian yang dapat ditangkap saat kejadian tersebut berlangsung. ${ }^{12}$ Dalam penelitian ini konselor melakukan observasi terhadap remaja yang merupakan objek penelitian. Kemudian teknik wawancara merupakan pertemuan dua orang untuk bertukar informasi dan ide melalui tanya jawab, wawancara dalam penelitian ini adalah wawancara bebas terpimpin yang artinya pertanyaan bebas namun sesuai dengan data yang akan diteliti. ${ }^{13}$

\section{HASIL DAN PEMBAHASAN}

Manusia adalah ciptaan Allah yang paling sempurna. Ia dibentuk oleh kehidupan, pengetahuan, nilai-nilai dan keyakinan yang melahirkan sikap. Sikap kita sering terjadi karena kebiasaan dan pengaruh dari luar. Oleh sebab itu sikap atau tindakan kita dipengaruhi oleh kebiasaan-kebiasaan kita. Dengan demikian pemikiran memiliki banyak kekuatan yang bisa mempengaruhi banyak hal, diantaranya: pikiran membuat arsip memori dalam akal, pikiran melahirkan mindset, pikiran mempengaruhi intelektualitas, pikiran mempengaruhi fisik, pikiran melahirkan kebiasaan, dan pikiran mempengaruhi sikap. ${ }^{14}$

Tatkala larangan didasarkan atas banyak berprasangka negatif, sedangkan Allah mengatakan bahwa manusia telah diciptakan dalam bentuk yang sebaik-baiknya, maka pemberitahuan dengan ungkapan ini intinya agar manusia menjauhi buruk sangka apa pun

10 Ahmad Putra Prasetio Rumondor, "Pendidikan Agama Islam Dalam Mencegah Kenakalan Siswa (Studi Kasus Di MA Muhammadiyah Lakitan Sumatera Barat)," Jurnal Educative: Journal of Educational Studies, Vol. 4, No. 1, 2019. hlm. 81-94.

${ }^{11}$ Lexy J, Moleong, Metode Penelitian Kualitatif, (Bandung: PT. Remaja Rosda Karya, 2005). hlm. 210.

12 Bimo Walgito, Bimbingan Konseling Studi dan Karir, (Yogyakarta: CV Andi Offset, 2010). hlm. 61.

13 Amani, "Peran Guru Bimbingan Dan Konseling Dalam Memotivasi Belajar Siswa SMP N 15 Yogyakarta," Hisbah: Jurnal Bimbingan Konseling dan Dakwah Islam Vol. 15, No. 1, 2018. hlm. 20-34.

14 Dinda Rizki Novia, "Terapi Rasional Emotif dalam Menangani Pikiran Negatif Seorang Anak Terhadap Ayah Tirinya di Yayasan Hotline Surabaya", Skripsi, Surabaya 2008, tidak dipublikasikan, hlm. 43. 
yang akan menjerumuskannya ke dalam dosa. Sebab, dia tidak tahu sangkaannya yang manakah yang menimbulkan dosa. Dengan cara inilah, Al-Qur'an membersihkan kalbu dari dalam agar tidak terkontaminasi dengan anggapan buruk pada diri. Tetapi, AlQur'an membiarkannya tetap bersih dan terbebas dari bisikan, keraguan dan kesangsian; serta hatinya tenteram tanpa terkotori kegelisahan dan gundah.

Pemberantasan negative thinking pada diri manusia sejalan dengan tujuan Al Qur'an yang hendak membersihkan akhlak dan kalbu. Namun, persoalan itu memiliki dampak yang lebih jauh dari pada hal tersebut. Yaitu, menjadi salah satu prinsip Islam yang utama dalam sistem kemasyarakatan dan dalam penerapan serta hukum. Negative thinking adalah cara seseorang memberikan penilaian atau kesimpulan secara bertolak belakang dari kenyataannya. Jadi, negative thinking dapat diartikan sebagai cara atau pola berpikir yang lebih condong pada sisi negatif dibanding sisi positifnya. Pola pikir ini bisa tampak dari keyakinan atau pandangan yang terucap, cara seseorang bersikap dan berperilaku seharihari. Pola pikir negatif juga tampak dari cara seseorang memandang atau merespon persoalan yang seringkali mengabaikan rasionalitas, logika, fakta atau informasi yang relevan. Berpikir adalah berbicara dengan diri kita sendiri dalam benak dan batin mereka masing-masing. Dari hal mempertimbangkan, merenungkan, mengamati, menganalisa dan membuktikan sesuatu serta menentukan hasilnya itulah yang dikatakan dengan berpikir.

Pikiran negatif bukanlah muncul begitu saja tanpa ada faktor yang menyebabkan ia muncul pada diri seseorang, berikut faktor-faktor penyebab berpikiran negatif, diantaranya: pertama, program terdahulu. Kedua, Tidak adanya tujuan yang jelas. Ketiga, Rutinitas negatif. Keempat, Pengaruh internal. Kelima, pengaruh eksternal. Keenam, kehidupan masa lalu. Ketujuh, konsentrasi yang negatif. Kedelapan, kondisi mental yang lemah. Kesembilan, Persahabatan yang tidak baik. Kesepuluh, media informasi.

Berpikiran negatif dengan diri adalah sebuah hal yang berlawanan dengan apa yang Islam ajarkan, karena pada intinya Allah SWT menginginkan semua umat manusia mampu hidup dengan cara yang telah ditunjukkan dan memanfaatkan potensi yang ada pada diri. Islam tidak menyukai hamba yang lemah, putus asa, tidak optimis dan menyerah. Tentunya hal yang demikian tidak sesuai dengan harapan dan tujuan hidup yang Tuhan inginkan serta kita sebagai manusia tidak menginginkan semua itu ada pada diri dan hati. Oleh karena itu, dengan pengabungan antara teknik RET dengan ayat al-qur'an ada semacam sebuah alur yang sama dalam menuntaskan sebuah pemikiran negative pada diri yang bersifat irasional/tidak logis kepada pikiran yang logis yang pada akhirnya membawa seseorang dapat termotivasi untuk bangkit dan introfeksi diri.

Dalam kasus ini, konselor memberikan pelayanan bimbingan konseling Islam dengan menggunakan teknik rational emotive therapy dalam menangani pikiran negatif seorang remaja terhadap tubuh yang ideal yang ia anggap menghambat dirinya dalam mencapai cita-cita menjadi seorang polisi. Dalam upaya ini, sasaran perubahan yang dilakukan ialah 
bagaimana pola pikir yang tidak rasional pada remaja tersebut dapat diubah agar tidak cepat dalam menyimpulkan kegagalan dengan keadaan tubuhnya yang tidak ideal. Ini dilakukan agar klien tersebut dalam berpikir dengan benar dan memikirkan baik-baik apakah masuk akal bila menyimpulkan secara cepat sebuah kegagalan di masa yang akan datang. Bimbingan kepada klien yang mengalami pikiran negatif seperti kasus ini sangat penting dilakukan karena apabila seseorang mudah berpikir negatif dari dini, maka akan mudah memunculkan permasalahan demi permasalahan dalam hidupnya. Konseling dan elaborasi dengan QS At-Tin ayat 4 ini dilakukan untuk merubah pola pikir atau sebuah persepsi buruk terhadap tubuhnya sendiri yang dikarenakan memiliki tubuh yang tidak ideal dan menganggap bahwa cita-citanya untuk menjadi seorang polisi telah sirna.

Dalam hal ini konselor menggunakan beberapa cara dalam mencari tahu kasus yang dialami oleh remaja ini yang mana ia negative thingking terhadap bentuk tubuhnya yang tidak ideal yang akibatnya ia menilai bahwa cita-citanya tidak akan tercapai dengan keadaan tubuh yang sekarang.

\section{Identifikasi Masalah}

Identifikasi masalah merupakan sebuah perencanaan awal pratindakan untuk pencatatan data pribadi individu yang dalam hal ini remaja, seperti konselor menanyakan nama lengkap remaja yang bersangkutan, alamat tempat tinggal dan lain sebagainya. ${ }^{15}$ Upaya yang pertama konselor lakukan ialah melakukan identifikasi masalah, sehingga konselor mengetahui apa sebenarnya yang dialami remaja dan yang menjadikan dirinya sulit optimis dalam mencapai cita-citanya menjadi polisi. Dengan mengetahui masalah yang dialami remaja ini, konselor mencari informasi yang lain sebagai penguatan kepada keluarga remaja dan orang-orang yang ada didekatnya. Konselor mencari informasi melalui orang tua, kakak dan teman sebaya klien. Dalam tahap ini, hubungan pribadi antara konselor dengan klien menjadi sangat penting karena hubungan yang hangat atau mendalam adalah kondisi yang diperlukan agar tercipta keterbukaan pada diri klien kepada konselor. ${ }^{16}$

Adapun data-data yang didapatkan dari sumber-sumber tersebut ialah :

a) Data dari klien

Terkait dengan kasus ini, klien memang menyadari bahwa ia sering merasa minder dan malu dengan keadaan tubunnya yang tidak ideal. Ia merasa bahwa ukuran tubuhnya terlalu gemuk dan merasa bahwa tidak akan mungkin bisa membentuk bentuk tubuh yang ideal yang pada akhirnya ia tidak bisa mencoba untuk ikut dalam mengikuti pendaftaran anggota kepolisian. Klien juga menyadari bahwa sering bermalas-malasan belajar karena ia

${ }^{15}$ Kadek Pigura Wiladantika, I Ketut Dharsana, dan Kadek Suranata, "Penerapan Konseling Behavioral Dengan Teknik Modeling Untuk Meminimalisir Perilaku Agresif Siswa Kelas XI Bahasa SMA Negeri 2 Singaraja," Undiksa: Bimbingan Konseling, Vol. 2, No. 1, 2014. hlm. 1-11.

16 Isop Syafe'i, "Aplikasi Rasional Emotif Terapi dalam Memperbaiki Perilaku Membolos Siswa," Psympathic: Jurnal Ilmiah Psikologi, Vol. 3, No. 2, 2010. hlm. 216-222. 
merasa kecewa dengan keadaan tubuhnya. "saya merasa malu dan tidak yakin bahwa akan bisa membentuk tubuh yang ideal lagi, cita-cita saya untuk menjadi anggota polisi telah sirna, saya sangat sedih,"17 tutur klien. Klien mengatakan bahwa sebenarnya ia bisa saja berdiskusi dan meminta pendapat kepada orangtua, akan tetapi karena terlalu sedih dan tidak optimis, klien hanya mendiamkan saja apa yang ia rasakan dan pada akhirnya ia selalu berpikiran negatif terhadap tubuhnya.

b) Data dari orangtua Klien

Ketika klien sedang di sekolah, konselor sempat menemui orangtua klien dan membahas permasalahan yang dialami oleh klien. Orangtua klien mengatakan, "anak saya memang pernah mengatakan bahwa ia ingin setelah selesai sekolah menengah untuk mencoba ikut mendaftar menjadi anggota polisi. Akan tetapi, ia sering terlihat menyalahkan dirinya sendiri karena tubuhnya yang tidak ideal dan terlalu gemuk. Saya sangat sedih dengan pikiran yang ada pada anak saya, entah kenapa ia bisa menilai buruk tubuhnya dan sering berkata yang tidak baik, padahal sekarang dia masih kelas 1 SMA, masih ada dua tahun lagi untuk memperbaiki tubuh bisa saja dia berolahraga dan jaga pola makan. Akan tetapi, dia terlalu cepat merasa gagal dan takut tidak bisa mencoba untuk mendftar menjadi anggota kepolisian".18

c) Data dari teman sebaya klien

Konselor dalam kasus ini juga sempat melakukan wawancara langsung dengan teman sebaya klien yang juga teman dekat sesama sekolah dan satu daerah. Teman sebaya klien mengatakan, "yang saya tahu, dia memang pernah mengatakan bahwa cita-citanya ingin menjadi anggota polisi dan setelah selesai SMA ini ia akan mencoba untuk mendaftar menjadi anggota polisi. Hanya saja, ia pernah mengatakan bahwa bentuk tubuhnya yang sedikit gemuk menjadi penghambat untuk mencapai cita-citanya menjadi seorang polisi. Ia juga sering marah dan kesal kepada saya ketika teman-temannya yang lain bertanya mengenai cita-cita kepadanya. Akan tetapi, saya tidak enak juga bila menanyakan hal itu lagi kepadanya".19

\section{Diagnosis}

Tahap kedua ialah melakukan diagnosis, diagnosis ialah suatu proses untuk melakukan analisa penyebab suatu masalah yang dialami oleh klien, yang dalam hal ini seorang remaja. ${ }^{20}$ Setelah melakukan upaya identifikasi masalah pada klien, konselor menemukan sebuah kesimpulan bahwa klien merasa tidak yakin dan merasa kecewa dengan tubuhnya yang tidak ideal, klien merasa putus asa serta sedih karena ia menganggap bentuk tubuhnya tidak mendukung dirinya menggapai cita-citanya untuk menjadi anggota polisi. Perasaannya menjadi campur aduk dan bingung harus bagaimana

17 Wawancara dengan RA, pada 5 Januari 2020, jam 10.00 WIB

18 Wawancara dengan GM, pada 7 Januari 2020, jam 16.00 WIB

19 Wawancara dengan RF, pada 12 Januari 2020, jam 17.00 WIB

20 Ida Ayu Diah Padma Dewi, Ni Nengah Madri Antari, dan Nyoman Dantes, "Penerapan Konseling Kognitif Sosial dengan Teknik Role Playing untuk Mengembangkan Sikap Empati pada Siswa Kelas XI IPS 1 SMA Negeri 3 Singaraja Tahun Ajaran 2013/2014," Universitas Pendidikan Ganesha, Vol. 2, No. 1, 2014. hlm. 1-11. 
memperbaiki bentuk tubuh agar dapat ideal sehingga dapat lebih siap ketika mendaftar menjadi anggota polisi.

Diagnosis ini juga semakin kuat dengan adanya sikap dan perilaku yang klien perlihatkan, diantaranya: menilai buruk tubuhnya, marah ketika teman-temannya menanyakan cita-citanya, tidak banyak bicara dengan orang tua, tidak semangat berolahraga dan merasa terbebani dengan pertanyaan serta ejekan teman-temannya. Imbas dari ini, klien semakin merasa sedih dan tidak optimis dalam menggapai cita-citanya.

\section{Prognosis}

Berdasarkan data dan kesimpulan yang didapatkan, konselor mencoba menerapkan sebuah teknik untuk membantu klien menghadapi permasalahannya dengan menggunakan rational emotive therapy dan dielaborasikan dengan QS At-Tin ayat 4. Alasan menggunakan terapi ini ialah untuk melakukan perubahan pola pikir pada diri klien agar tidak cepat berpikir negatif terhadap tubuh dan mengubah pola pikir yang optimis. Di samping itu, diharapkan klien tidak cepat merasa gagal dan putus asa dalam menggapai harapannya menjadi anggota kepolisan hanya dengan bentuk tubuh yang tidak ideal.

Adapun upaya yang dilakukan dalam prognosis oleh konselor terkait kasus ini, diantaranya : pertama, klien diberikan pemahaman dan nasehat bahwa perlunya berpikir jernih terhadap sebuah masalah yang dialami. Konselor memberikan pemahaman bagaimana cara berpikir yang rasional dan bagimana cara mengubah sebuah pikiran yang tidak rasional. Dengan langkah ini, klien tahu bahwa manusia itu memiliki sebuah potensi, sebuah upaya dan dapat mencapai apa yang diharapkan. Kedua, konselor mencoba meyakinkan kepada klien bahwa tubuh yang ideal dapat dibentuk, seseorang yang tubuhnya gemuk atau kurus pun akan menjadi ideal bila ada niat dalam membentuk tubuh serta mengatur pola makan yang benar. Semuanya tergantung dari niat dan usaha dari masing-masing orang yang bersangkutan saja.

Ketiga, dalam hal ini, konselor mencoba mengelaborasikan antara nasehat dalam proses konseling dengan nilai keagamaan yang ada dalam QS. At-Tin ayat 4, yang mana dijelaskan bahwa manusia diciptakan dalam bentuk yang sebaik-baiknya dan sempurna dihadapan Allah. Konselor dalam hal ini mencoba mengutip penjelasan dari Muhammad Fuad Abdul Baqi yang mana didalam kamus bahasa Arab, kata ahsan mengandung arti sebaik-baiknya. Pada kamus akbar, ahasan berarti berbuat baik. dalam kamus kontemporer, artinya yang lebih baik, utama, indah dan terbaik. Banyak makna yang terdapat dalam kata ahsan dalam QS At-Tin ayat 4. Begitupun dengan kata taqwim yang artinya bentuk fisik yang sesuai dengan fungsinya masing-masing, yang secara keseluruhan berarti kesempurnaan sesuatu dalam objeknya. ${ }^{21}$

21 Deddy Permadi, Konsep Ahsan Taqwim dalam Surat At-Tin Ayat 4 (Studi tentang Disabilitas), Skripsi, (Medan: Program Studi Ilmu Al-Qur'an dan Tafsir UIN Sumatera Utara, 2019), hlm. 55. 
Kata ahsan taqwim berarti sebaik-baiknya itu lebih baik, lebih indah yang optimal adanya. Konselor mencoba mendiskusikan dan berbagai kepada klien bahwa sejatinya manusia telah diciptakan dengan kondisi yang baik termasuk psikis dan fisik tentunya. Klien dapat berjalan, berpikir dan menjalani keseharian itu semua karena kesempurnaan yang Dia beri, bahkan tubuh yang kita miliki lebih indah dan sempurna ketimbang dari makhluk lainnya yang Dia ciptakan. ${ }^{22}$

Konselor juga mengatakan bahwa bahwa klien diciptakan dengan anggota tubuh yang sempurna dan lengkap, tentunya dapat mensyukuri semua yang ada saat ini, dapat beraktivitas dengan baik, berkumpul bersama orang-orang tersayang dan yakinlah bahwa semua yang Allah beri kepada klien tidaklah sia-sia. Allah telah menjadikan setiap manusia dalam bentuk yang sebaik-baiknya keadaan dan menjadikan manusia berperawakan tegak hanya saja manusia sering lalai dan sesekali ada yang tidak memahaminya. Maka dengan itu, klien ataupun semua orang mesti memahami bahwa menganggap diri kita sendiri lemah adalah kesimpulan yang salah dan mulailah mensyukuri fisik serta kesehatan yang dimiliki saat ini.

Selanjutnya, konselor juga meminta klien untuk memanfaatkan waktu luang untuk membaca ayat al-qur'an terkhusus Q.S At-Tin ayat 4 serta memahami maknanya. Bagaimana pun, isi al-qur'an memberikan banyak pengetahuan dan solusi dalam setiap masalah yang datang dalam kehidupan. Hamdani Ali menjelaskan bahwa al-qur'an adalah bacaan terbaik untuk semua umat muslim karena ada ibadah yang akan diraih dalam mengerjakannya dan tentunya pahala yang telah Allah persiapkan untuk yang membacanya. ${ }^{23}$

Ayat al-qur'an digunakan agar klien dapat menyadari bahwa ia telah salah dalam menilai dirinya dan perlu memperbaiki pola pikir agar tidak mudah menyalahkan keadaan tubuhnya. Keempat, konselor menyarankan klien untuk mengubah pola pikirnya yang selama ini negative thingking terhadap tubuh yang tidak ideal dan masa depannya kelak. Klien digiring untuk percaya diri, optimis dan yakin bahwa akan mampu mencapai cita-cita yang diinginkannya asalkan berusaha dan berdoa dalam menggapainya.

\section{Terapi (Treatment)}

Dalam melakukan upaya dan terapi kepada klien, konselor telah melakukan beberapa kali pertemuan, berikut penjelasannya : pertama, konselor melakukan pertemuan pada tanggal 12 Januari 2020 pada pukul 14.00 WIB. Dalam hal ini, konselor mengajak klien untuk berdiskusi dan menyampaikan bahwa apa yang akan dibahas akan dirahasiakan dengan baik. Klien diminta untuk menyampaikan semua beban yang ia rasakan, semua

22 Tim Pustaka Phoenik, Kamus Besar Bahasa Indonesia, Terj. Edisi Baru, (Jakarta : 2009). hlm. 99.

${ }^{23}$ Siti Fatimah, "Penerapan Teknik Student Team Archive Division (Stad) dalam Memahami Materi Bacaan Al-Qur'an Surah Al Hujurat Ayat 12 dan Ayat 10 di Kelas X DPIB 3 SMK Negeri 1 Jamblang Kabupaten Cirebon," Syntax Literate: Jurnal Ilmiah Indonesia, No. 4, No. 3, 2019. hlm. 167178. 
yang menjadi masalah dipikirannya dan terbuka. Kedua, konselor kembali melakukan pertemuan di malam hari setelah selesai shalat Isya pada tanggal 17 Januari 2020. Dalam pertemuan ini, konselor menanyakan perubahan apa yang telah klien lakukan dan bagaimana perasaannya sekarang. Klien mengatakan bahwa ia menyadari bahwa ia telah salah dalam berpikir dan merasa bodoh bila tidak bisa berubah. Klien mengatakan bahwa ia akan berupaya untuk merubah kebiasaan buruk dan mengubah pola pikir yang ia anggap selama ini benar.

Hanya saja, belum banyak yang bisa dilakukan klien dalam mengubah pola pikirnya. Ketiga, konselor kembali melakukan pertemuan dengan klien pada tanggal 20 Januari 2020 pada pukul 15.00 WIB. Konselor meminta klien untuk menyampaikan kembali seperti apa perasaannya saat ini dan memberikan kesempatan kepada klien untuk bercerita tentang pikirannya sekarang. Menariknya, klien telah tersadarkan bahwa apa yang ia pikirkan selama ini tidak memberikan manfaat buat dirinya sendiri sehingga ia mudah putus asa dengan sebuah masalah yang datang. Klien mengatakan bahwa sekarang ia akan mencoba berpikir yang benar dan tidak ingin cepat menilai buruk tubuh yang seperti sekarang. Dalam pertemuan ini, konselor juga menambahkan wawasan kepada klien untuk belajar bersyukur terhadap tubuh yang telah Allah berikan, pandai untuk menikmati kesehatan dan raga yang telah Allah anugerahkan. Dengan ini, klien diharapkan dapat berpikiran positif dan tidak cepat menilai buruk dirinya sendiri. Sehingga semangat dalam meraih citacita dapat selalu terhidupkan, yang penting ada usaha dan berdoa dalam meraih apa yang diinginkan.

\section{Evaluasi}

Seiring dengan proses terapi yang dilakukan dari awal sampai akhir, konselor telah berusaha semaksimal mungkin untuk membantu klien agar dapat mengubah pola pikir yang negatif menjadi pikiran yang dapat diterima akal. Dengan proses yang telah dilakukan, terlihat bahwa klien telah memperlihatkan antusias yang bagus, seperti rajin berolahraga, mendengarkan nasehat orangtuanya dan menjaga pola makan tentunya. Klien juga menyadari bahwa ia tidak boleh lemah dan patah semangat dalam meraih cita-citanya menjadi anggota polisi, banyak cara yang bisa klien lakukan seperti menjaga pola makan, banyak bergerak dan memahami motivasi yang ada dalam QS At-Tin ayat 4. Konselor berharap semoga klien selalu optimis dan semangat meraih cita-citanya, tidak cepat merasa lemah dan gagal serta yakin bahwa dibalik usaha akan ada hasil yang akan diterima.

\section{KESIMPULAN}

Berdasarkan penelitian yang telah dilakukan terkait dengan permasalahan yang dialami seorang remaja yang menilai negatif tubuhnya yang tidak ideal. Diketahui bahwa klien sulit menerima keadaan tubuhnya yang tidak sesuai dengan apa yang ia harapkan dan ia menilai bahwa itu menjadi hambatan dirinya untuk mencapai cita-citanya menjadi seorang anggota kepolisian. Dengan diberikannya pelayanan konseling melalui teknik 
rational emotive therapy dan dielaborasikan dengan QS At-Tin ayat 4 oleh konselor, klien mendapatkan pemahaman bahwa perlunya berpikiran yang rasional dan pantas. Disamping itu, konselor juga melakukan pertemuan dengan klien dan memotivasi klien untuk merubah cara berpikirnya dan meyakinkan hal-hal yang positif untuk masa depannya. Seiring berjalannya waktu, klien dapat mengenali dirinya, mampu berpikir rasional dan menyadari bahwa apa yang ia lakukan selama ini ialah sebuah kesalahan yang harus rubah. Melalui terapi ini, klien berjanji untuk optimis, semangat mencapai cita-citanya, teratur berolahraga, menjaga pola makan, tidak cepat merasa lemah, tidak takut gagal, dan yang terpenting bersyukur atas tubuh yang telah Allah berikan.

\section{DAFTAR RUJUKAN}

Albaar, Hoiruddin Ragwan, "Bimbingan Konseling Dalam Mengatasi Persepsi Negatif Siswa Terhadap Guru Bk Melalui Terapi Rasional Emotif Di SMP Jati Agung Sidoarjo," Jurnal Bimbingan dan Konseling Islam 04, no. 01 (2014): 95-105.

Amani, "Peran Guru Bimbingan Dan Konseling Dalam Memotivasi Belajar Siswa SMP N 15 Yogyakarta," HISBAH: Jurnal Bimbingan Konseling dan Dakwah Islam 15, no. 1 Juni (2018): 20-34.

Batubara, Jose RL, “Adolescent Development (Perkembangan Remaja)," Sari Pediatri 12, no. 1 Juni (2010): 21-29.

Corey, Gerald, Teori dan Praktek Konseling dan Psikoterapi, Bandung: Refika Aditama, 2013.

Gunarsa, Singgih D., Konseling dan Psikoterapi, Jakarta: Gunung Mulia, 1992.

Dewi Ida Ayu Diah Padma, Ni Nengah Madri Antari, dan Nyoman Dantes, "Penerapan Konseling Kognitif Sosial Dengan Teknik Role Playing Untuk Mengembangkan Sikap Empati Pada Siswa Kelas XI IPS 1 SMA Negeri 3 Singaraja Tahun Ajaran 2013/2014," e-journal Universitas Pendidikan Ganesha2 2, no. 1 (2014): 1-11.

Fatimah, Siti, "Penerapan Teknik Student Team Archive Division (Stad) Dalam Memahami Materi Bacaan Al-Qur'an Surah Al Hujurat Ayat 12 Dan Ayat 10 di Kelas X DPIB 3 SMK Negeri 1 Jamblang Kabupaten Cirebon," Syntax Literate : Jurnal Ilmiah Indonesia 4, no. 3 Maret (2019): 167-178.

Herabadi, Astrid Gisela, "Hubungan Antara Kebiasaan Berpikir Negatif Tentang Tubuh Dengan Body Esteem Dan Harga Diri," Makara: Sosial Humaniora 11, no. 1 Juni (2007): 18-23.

Jahja, Yudrik, Psikologi Perkembangan, Jakarta: Kencana, 2011.

Jannah, Miftahul, "Remaja Dan Tugas-Tugas Perkembangannya Dalam Islam," Jurnal Psikoislamedia 1, no. 1 April (2016): 243-256.

Lubis, Namora Lumongga, Memahami Dasar-dasar Konseling Dalam Teori dan Praktik, Jakarta:Kencana, 2011. 
Muawanah Elis dan Yusria Ningsih, "Bimbingan Konseling Keluarga Dengan Loving Kindness Therapy Dalam Meningkatkan Regulasi Emosi," Jurnal Bimbingan dan Konseling Islam 03, no. 2 (2013): 152-162.

Moleong, Lexy J, Metode Penelitian Kualitatif, Bandung: PT. Remaja Rosda Karya, 2005.

Nazir, Moh, Metode Penelitian, Jakarta: Ghalia Indonesia, 1988.

Novia Dinda Rizki, Terapi Rasional Emotif Dalam Menangani Pikiran Negatif Seorang Anak Terhadap Ayah Tirinya Di Yayasan Hotline Surabaya, Skripsi, Surabaya 2008, tidak dipublikasikan.

Permadi, Deddy, Konsep Ahsan Taqwim dalam Surat At-Tin Ayat 4 (Studi Tentang Disabilitas), Skripsi, Medan: Program Studi Ilmu Al-Qur'an dan Tafsir UIN Sumatera Utara, 2019.

Putro, Khamim Zarkasih, "Memahami Ciri Dan Tugas Perkembangan Masa Remaja," Aplikasia: Jurnal Aplikasi Ilmu-ilmu Agama 17, no. 1 (2017): 25-32.

Putra Ahmad dan Prasetio Rumondor, "Pendidikan Agama Islam Dalam Mencegah Kenakalan Siswa (Studi Kasus Di MA Muhammadiyah Lakitan Sumatera Barat)," Jurnal Educative: Journal of Educational Studies 4, no. 1 Januari (2019): 81-94.

Putra, Ahmad, "Motivasi Marbut Masjid Di Kelurahan Anduring Kecamatan Kuranji Kota Padang (Studi Terhadap Mahasiswa UIN Imam Bonjol Padang)," Nuansa Jurnal Penelitian Ilmu Sosial dan Kegamaan Islam 16, no. Juli (2019): 223-235.

Putra, Ahmad, "Metode Konseling Individu Dalam Mengatasi Bolos Sekolah Siswa Kelas VIII SMPN 3 Lengayang Sumatera Barat," Hisbah: Jurnal Bimbingan Konseling dan Dakwah Islam 16, no. 2 Desember (2019): 112-126.

Rahman, Imas Kania, "Konsep Pendekatan Rational Emotive Behavior Therapy (Rebt) Berbasis Islam Untuk Membangun Perilaku Etis Siswa," Genta Mulia VIII, no. 2 Juli (2017): 13-26.

Rahmayani Andi dan Syisnawati, "Mengontrol Pikiran Negatif Klien Skizofrenia Dengan Terapi Kognitif," Journal of Islamic Nursing, Vol. 3, no. 1 Juli (2018): 46-54.

Saputra, Andi Tri, "Konsep Intelijen dan Penafsiran Kontekstualitas Terhadap Q.S AlHujarat Ayat 12 (Aplikasi Metode Penafsiran Kontekstualis Abdullah Saeed," Nun 5, no. 2 (2019): 93-125.

Saeed, Abdullah, Al-Qur'an Abad 21: Tafsir Kontekstual, terj. Ervan Nurtawab, Bandung: Mizan, 2016.

Sukardi, Dewa Ketut, Pengantar Teori Konseling; Suatu Uraian Ringkas, Jakarta: Ghalia Indonesia, 1985.

Sulistyarini dan Mohammad Jauhar, Dasar-dasar Konseling, Jakarta: Prestasi Pustakarya: 2014.

Syafe'I, Isop “Aplikasi Rasional Emotif Terapi Dalam Memperbaiki Perilaku Membolos Siswa," Psympathic, Jurnal Ilmiah Psikologi III, no. 2 (2010): 216-222.

Tim Pustaka Phoenik, Kamus Besar Bahasa Indonesia, Terj. Edisi Baru, Jakarta : 2009. 
Walgito, Bimo, Bimbingan Konseling Studi dan Karir, Yogyakarta: CV Andi Offset, 2010.

Wiladantika Kadek Pigura, I Ketut Dharsana, dan Kadek Suranata, “Penerapan Konseling Behavioral Dengan Teknik Modeling Untuk Meminimalisir Perilaku Agresif Siswa Kelas XI Bahasa SMA Negeri 2 Singaraja," e-journal Undiksa Jurusan Bimbingan Konseling 2, no. 1 (2014): 1-11.

Willis, Sofyan S., Konseling Individual Teori dan Praktek, Bandung: Alfabeta, 2014.

Yusuf, Muri, Metode Penelitian Kuantitatif, Kualitatif \& Penelitian Gabungan, Jakarta: Prenadamedia Group, 2014. 